\title{
ADDRESSING AND ELIMINATING THE MISCONCEPTIONS ABOUT ACID AND BASES CONCEPTS IN PRIMARY SCHOOL CHEMISTRY TEACHING
}

\author{
Keti Ivanoska ${ }^{1}$, Marina Stojanovska ${ }^{2 *}$ \\ ${ }^{1}$ Goce Delčev Primary School, Prilep, Republic of Macedonia \\ ${ }^{2}$ Institute of Chemistry, Faculty of Natural Sciences and Mathematics, \\ Ss. Cyril and Methodius University, Skopje, Republic of Macedonia \\ marinam@pmf.ukim.mk
}

\begin{abstract}
The research was conducted in the period from March to June 2019 to address the prevalence of misconceptions among primary school students regarding the acids and bases concepts and to design appropriate interventions. The sample consisted of $470,8^{\text {th }}$ and $9^{\text {th }}$ grade students from seven schools in Macedonia, divided into two groups: a control group (CG) and an experimental one (EG). The students' conceptual knowledge was examined, on the basis of which the students were divided into 4 groups: satisfactory conceptual understanding, roughly adequate performance, inadequate performance, and quite inadequate performance. Both quantitative and qualitative methods were included to conduct more comprehensive research and obtain more relevant results. The analysis of the pre- and post-tests showed significantly better results in the experimental group indicating the efficiency and applicability of the teaching intervention. Several misconceptions were detected among the students, but they were reduced or eliminated after the applied intervention.
\end{abstract}

Keywords: acids and bases; chemistry teaching; misconceptions; primary education

\section{ЛОЦИРАЫЕ И ОТСТРАНУВАЊЕ НА ПОГРЕШНИТЕ ПРЕТСТАВИ ВО ВРСКА СО КОНЦЕПТИТЕ ЗА КИСЕЛИНИ И БАЗИ ВО НАСТАВАТА ПО ХЕМИЈА ВО ОСНОВНОТО ОБРАЗОВАНИЕ}

Истражувањето беше спроведено во периодот од март до јуни 2019 година со цел да се испита распространетоста на погрешните претстави кај учениците од основните училишта во врска со концептите за киселини и бази и да се осмислат соодветни интервенции. Примерокот се состоеше од 470 ученици од 8. и 9. одделение од седум училишта во Македонија, поделени во две групи: контролна група (КГ) и експериментална група (ЕГ). Се испитуваше концептуалното знаење на учениците, врз основа на кое учениците беа поделени во 4 групи: добро концептуално разбирање, задоволително концептуално разбирање, недоволно концептуално разбирање и целосно неприфатливо концептуално разбирање. Применети беа и квантитативни и квалитативни методи за да се спроведе посеопфатно истражување и да се добијат порелевантни резултати. Анализата на пре- и пост-тестовите покажа значително подобри резултати во експерименталната група, што укажува на ефикасноста и применливоста на интервенција. Неколку погрешни претстави беа откриени кај учениците, но тие беа редуцирани или целосно отстранети по применетата интервенција.

Клучни зборови: киселини и бази; погрешни претстави; настава по хемија; основно образование

\section{INTRODUCTION}

The idea for this research originates from the previous experience of the authors as chemistry teachers (at university and in primary school) in the realization and monitoring of the chemistry teaching in the $8^{\text {th }}$ and $9^{\text {th }}$ grades. Namely, during the realization of the lessons, as well as the as- 
sessment of students' knowledge, it was noticed that the students acquire (or have already acquired) erroneous notions (wrong ideas about chemistry concepts, well known as misconceptions). Oftentimes, these misconceptions are so deep-rooted that even the every-day indication and the attempt to change these ideas is rarely effective. The problem of efficient acquisition of knowledge and elimination of misconceptions is becoming more and more relevant, and the experiment in teaching chemistry, as an essential part of teaching methods, can not only greatly contribute to easier acquisition of knowledge, but also to the elimination of misconceptions.

In the literature one can find several names that refer to the erroneous notions. Thus, the terms misconceptions or preconceptions are used, but, according to some authors [1], the term alternative conceptions is the most appropriate. The term misconception is defined as an idea, opinion or perception that is wrong because it is based on a misunderstanding of a particular situation [2]. No matter what the misconceptions are called, there are many reasons to identify and study them. Understanding scientific concepts is important, but equally important is the level of understanding and identification of students' misconceptions [3]. Identifying key misconceptions can also help in curricula development.

Misconceptions in chemistry can stem from prior knowledge, everyday or specific scientific terminology, or from the statements presented in textbooks and other teaching materials [4]. Misconceptions stemming from the teaching process are known as "school-made" misconceptions [5]. Some of the reasons for the appearance of misconceptions can be located in the problems with the specific terminology, especially in the introduction of the concepts of substances, the particles from which they consist, and the chemical symbols and formulae used to represent them. Some authors [6,7] argue that the definitions for most fundamental concepts are problematic, noting that many basic chemical concepts are difficult to learn because of insufficiently precise definitions or such that refer to ideas that beginners (in our case, primary school students) are not familiar with and must accept them "by heart" [4]. An example of a misconception that is deeply ingrained in the minds of students and was of interest to this research is that acid is something that "eats" material or can burn us.

Misconceptions can prevent students from understanding the concept, especially basic concepts such as those about acids and bases. According to Artdej et al. [8] the theory of acids and bases is a difficult concept not only for primary and secondary school students, but also for undergraduate students. To overcome this, the misconceptions must first be identified. However, in the process of identifying misconceptions, it is difficult to distinguish between students who have misconceptions, those who only guess the answer because they do not understand the concept (lack of knowledge), and those who really understand the concept well [9]. The analysis of misconceptions is intended to locate misconceptions and to find out the difficulties in students' learning [10].

In recent decades, research on the topic of misconceptions in chemistry teaching has acquired great relevance. Much research has been done to predict potential misconceptions regarding acids and bases [8, 11-16], as they are most common during teaching and are likely to lead to students' comprehension problems if not eliminated in the early stages of the study of chemistry. In their research Artdej et al. [8] discovered that students exhibited the most misconceptions regarding the acid-base theory. Shepard [13] interviewed 16 high school students about their understanding of titrations and related acid base phenomena using microcomputer-based labs and questioned their understanding by the ability to explain phenomena and use drawings to support their reasoning. Based on his findings, he points out that students have poor understanding of $\mathrm{pH}$ and acid-base concepts, and that this should be an indication for the teachers, textbook authors, and curricula developers. Cooper et al. [17] developed an assessment protocol to capture the students' reason about acid-base reactions which was based on open-ended questions. They advise instructors about the structure of the prompts used to elicit students thinking in a way not only to ask them for an explanation, but also to provide students with some structure about what is expected in their response.

Teachers usually guide students to use their ideas and come to conclusions. This makes scientific concepts easier to understand. Students are expected to revise their misconceptions so they can accept and use the scientific concept to solve problems [10]. For this to be possible, a conceptual change is needed [18]. The positive effect of a conceptual change instruction in improving students' understanding has been confirmed in many studies dealing with misconceptions [3, 19-22], even in the online setting [23]. Additionally, such instructions are even more effective if they are connected to real world issues, in that way improving students' attitudes towards learning science and increasing their motivation [24]. 
According to Posner et al. [25] learning is the result of the interaction between what the student is taught and his/her current ideas or concepts. Authors compare learning to a kind of inquiry, seeing the learning process as a process of conceptual change where the student must make judgments based on the evidence. In certain cases, students use their previously formed concepts to grasp the phenomena (assimilation), while oftentimes these concepts are insufficient for solid scientific understanding. In the latter case, a more radical form of conceptual change is needed (accommodation). The authors further list four conditions that must be met in order for accommodation to occur: 1) there must be dissatisfaction with existing conceptions, 2) a new conception must be intelligible, 3) a new conception must appear initially plausible, and 4) a new concept should suggest the possibility of a fruitful research program.

Vosniadou et al. [26] critiqued the classical approach to conceptual change and reasoned that students should first become aware of their existing conceptual structures and beliefs, and then slowly change them with scientifically accepted ones. This is hard work because students already have well established explanations which function quite well for them and fit into their mental network. To motivate students to re-examine their views the teaching instruction should provide such a learning environment in which students will have the opportunity to independently experience the phenomenon and truly understand the concept, not only in the form of enrichment of previous knowledge, but also recognition of previous experiences and acquired knowledge of students and creation of new representations, which further leads to the creation of lasting knowledge.

Duit and Treagust [21, 27] argue that the term conceptual change is often misunderstood and seen as replacing previous concepts with new, scientific ones. These authors elaborate that students' pre-instructional conceptual structures should be fundamentally restructured allowing them to gain new knowledge and grasp scientific concepts. In addition to cognition, affective factors are also important for engagement in educational learning activities, such as motivation, interest, selfefficacy, and students' beliefs [28].

One of the reasons that chemistry is difficult to learn is that it has multiple levels of thinking, i.e. the presentation of concepts. Many misconceptions occur due to improper application of the three levels of thinking in chemistry or due to neglecting the microscopic level from the explanations [2932]. While including three levels of representation in chemistry teaching can reduce the development of new misconceptions and correct already existing ones, it can still happen that such submicroscopic representations are a source of misconceptions [33].

Namely, knowledge in chemistry is acquired on three levels [34]: 1) macroscopic - what can be seen, touched, or smelled, 2) microscopic - atoms, ions, molecules, and chemical structures, and 3) symbolical - symbols, formulae, equations, and graphs. None of these levels of thinking are superior, but they build on each other. The triple nature of chemical concepts in primary education is first mentioned in the $8^{\text {th }}$ grade chemistry textbook [35]. Namely, as an explanation for the representation given in the textbook (Fig. 1), it is stated that all three representations "describe the water", but in a different way. The glass of water represents what we can see, touch, hear, smell or taste. The representation ' $a$ ' shows the way we imagine the particles from which substances are made, and the representation ' $c$ ' represents the symbolic level."

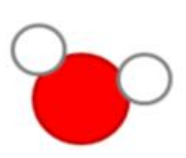

a

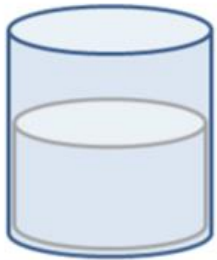

b

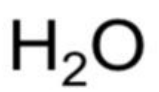

Fig. 1. Three representations of water: molecular model (a), glass of water (b) and chemical formula (c)

Still, in explaining the representation 'a', microscopic level, an insufficiently precise explanation is given due to generalization rather than talking specifically about the water molecule ("representation ' $a$ ' shows the way we imagine the particles from which substances are made").

Distinguishing between macroscopic and microscopic views is very important [36], as is the gradual introduction of chemical concepts, starting with macroscopic observation and then moving on to microscopic explanations. This is in line with the constructivist approach [7, 37], according to which the learning process must take place in small steps. With the gradual introduction of the three levels of thinking, many misconceptions can be avoided. Thus, for example, the study of a concept, if appropriate to the content, may begin with an experiment. Students will notice the changes and they will be explained on a macroscopic level. Then, by discussing the par- 
ticles that interact with each other, drawings, diagrams, and molecular models can be used to explain the microscopic level, and then move on to the symbolic level, using chemical symbols and chemical formulae.

\section{EXPERIMENTAL SECTION}

\subsection{Instructional content}

Primary school chemistry is taught according to the chemistry curricula developed by the Cambridge International Examinations and adapted by the Bureau of the Development of Education [38] and was the first implemented in the 2016/2017 academic year. The curriculum contains elements of scientific research, which includes reviewing ideas, evaluating evidence, planning research work, and observing and analyzing data. Scientific research enables the development of self-confidence and interest in science. However, the conducted teacher trainings were not enough. Moreover, the schools need to have chemistry laboratories and available resources (laboratory equipment and chemicals, as well as additional literature for teachers and students) as the experiment plays a key role in scientific research.

In this research, in the $8^{\text {th }}$ grade the concepts of the Use of acids and bases teaching content were covered, while in the $9^{\text {th }}$ grade the Obtaining salts from hydroxides teaching content was realized. During the lesson, in the experimental group the definitions of bases and acids, the products of the neutralization reaction, the particle theory of matter, the $\mathrm{pH}$ value of different solutions, and the application of indicators were discussed. Based on the chemistry curricula for the $8^{\text {th }}$ and $9^{\text {th }}$ grades, students should know that acids and bases neutralize each other, forming salt and water, in a process called neutralization. In practice, this type of reaction can be performed by titration using an indicator that changes color when the base and acid are in stoichiometric ratio.

\subsection{Methodology}

\subsubsection{Objectives of the study}

The purpose of the research was to gain insight into the knowledge and address the possible misconceptions that students have in relation to some chemical concepts. The research referred to the identification of misconceptions about acids and bases, as well as other chemistry concepts that are necessarily related to the topic, such as physi- cal and chemical changes, indicators, the structure of substances, their solubility, etc.

This research, in addition to identifying misconceptions, was also aimed at developing appropriate guidelines (instructions) as part of the lessons. Within the framework of such instructions, several well-known experiments were applied, enabling active involvement of students in the experimentation. The purpose of these instructions was to improve students' progress as a result of conceptual change and reduce the number of misconceptions.

The following research questions were investigated:

1. Does the implemented intervention contribute to the improvement of students' knowledge and achievements?

2. Is there a trend in the perceptions of the $8^{\text {th }}$ and $9^{\text {th }}$ grade students?

3. Are there (if yes, which) misconceptions about the acids and bases concepts among students?

\subsubsection{Design}

The research consisted of two parts: quantitative (distribution of test according to pre-testpost-test design) and qualitative (realization of individual interviews with students). This paper presents only the quantitative results, and more comprehensive observations are expected after the analysis of the qualitative data (interview transcripts).

The teaching was carried out on a scheduled basis in different CG and EG classes. The intervention was applied during the lessons in EG to help in better understanding the concepts, in correcting the misconceptions that were observed in the students, and in encouraging active learning, which would increase the interest and motivation of the students as well as their involvement in the teaching process. It included in-depth explanations, the use of molecular models, experiments and discussion, and was supplemented by interviewing some of the students. We believed that models could be of great use in visualizing the particles of substances and would help explain the definition of acids and bases. Additionally, classroom discussion based on problem solving could make students aware of their misconceptions, which further leads to acquiring new, scientifically accepted, knowledge.

The teaching in both CG and EG was carried out according to the national curricula and was a combination of development and review lessons. 
We were interested in achieving several learning objectives defined in the curricula: distinguish between acidic, basic, and neutral solutions using indicators and $\mathrm{pH}$ scale, make predictions using scientific knowledge and understanding, test predictions using evidence and understand neutralization and some of its applications. These learning objectives are upgraded in the $9^{\text {th }}$ grade such that students should have a more detailed knowledge of the different ways of obtaining salts and the nomenclature of inorganic compounds. However, the focus was on the common learning objectives for the $8^{\text {th }}$ and $9^{\text {th }}$ grades.

Furthermore, some of the learning objectives relate to experimental work (e.g., correct use of different equipment, use of different materials and equipment and use precautions, make observations and measurements) and require independent investigation within regular classes. What is important to note is that not all schools in the country are equally equipped with laboratory equipment and chemicals, so, in general, the level of experimental teaching is different. Still, most of the schools involved in this research had some equipment and the teachers performed experiments in class. In addition, the activities proposed in the curricula are optional, i.e. the teacher decides which activities to use to achieve the learning objectives. Some of the proposed activities include dilution of acids, dissolution of bases, $\mathrm{pH}$ test and discussion of acidic or basic solutions, preparation of own indicators and their testing in different solutions, discussion of the neutralization reaction and the resulting products, performing a titration, and the recording and analysis of results.

In the experimental group, guided by the activities in the curricula, solutions of acids and bases with different concentrations were offered for testing, as well as solutions of different salts. Given that one of the most deep-rooted misconceptions is that a neutralization reaction produces a neutral solution so that all salts are neutral [3, 39], the idea was for students, through their own investigation, to convince themselves that solutions of different salts are not always neutral. This is certainly not a new discovery in a scientific sense, but it is a significant discovery for students. They get the opportunity to experience cognitive conflict and face their misconceptions, and thus have the best chance of eliminating or correcting them. Similarly, the study of Ural and Gençoğlan [40] was aimed to provide hands-on laboratory experiments among the $8^{\text {th }}$ grades to investigate the effect of argumentation-based science teaching approach about acids and bases. Experiential learning is valuable for students as they learn more effectively when doing rather than listening. They need meaningful experiences (for example, hands-on experiments) to address their (erroneous) beliefs which further influence interpretation of scientific information and the need of revision of certain misconceptions [26].

The emergence of misconceptions can be amplified by making generalizations. For example, the $8^{\text {th }}$ grade chemistry curriculum, as an explanation of the $\mathrm{NaOH}$ and $\mathrm{HCl}$ neutralization product, states "sodium chloride, salt (neutral)". If no other examples and in-depth explanations follow, and discussions and experimental work are offered, the misconception that all salts are neutral in solution may arise. Our assumption is that this was done because of the age of the students, but it is known that what is learned first is forgotten last. If the initial concepts in the study of a subject are set on the wrong basis, it is very likely that misconceptions will occur in further education. Therefore, the purpose of the proposed instruction was to create cognitive conflict in students and to create a learning environment to foster meaningful learning in the hope that this would lead to a reduction in the prevalence of misconceptions.

The experiments (Fig. 2) planned and realized during the research were:

- diluting concentrated sulfuric acid in different ratios, estimating and determining the $\mathrm{pH}$ of the obtained solutions with a universal indicator,

- dissolving granules of sodium hydroxide, estimating and determining the $\mathrm{pH}$ of the resulting solution with a universal indicator,

- performing a neutralization reaction between standardized solutions of sodium hydroxide and hydrochloric acid in the presence of a methyl orange indicator, and

- dissolving $\mathrm{NaCl}, \mathrm{NH}_{4} \mathrm{Cl}, \mathrm{K}_{2} \mathrm{CO}_{3}$ and $\mathrm{Na}$ $\mathrm{HCO}_{3}$ in water, estimating and determining the $\mathrm{pH}$ of the obtained solutions with a universal indicator.

In addition to conducting experiments, during the lessons physical and chemical changes, particles from which substances are made, acidity of solutions, color change of indicators when added to acids, bases and salt solutions, and other related topics were discussed. 


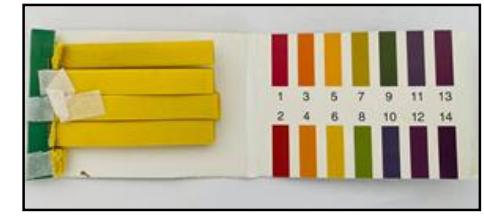

a) Universal indicator paper

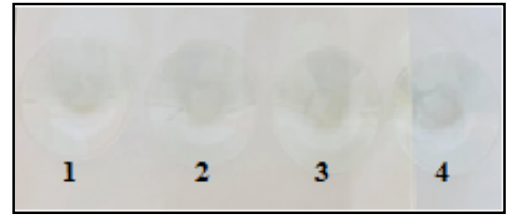

b) 1) $98 \% \mathrm{H}_{2} \mathrm{SO}_{4}$; 2) $\mathrm{H}_{2} \mathrm{SO}_{4}(1: 10)$; 3) $\mathrm{H}_{2} \mathrm{SO}_{4}(1: 30)$; 4) $\mathrm{H}_{2} \mathrm{SO}_{4}(1: 100)$

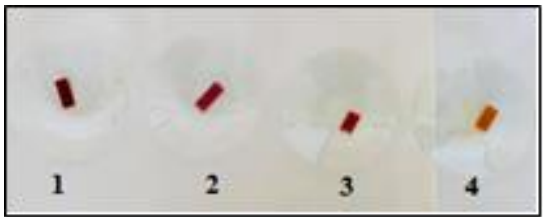

c) Determining the $\mathrm{pH}$ of $\mathrm{H}_{2} \mathrm{SO}_{4}$ solutions

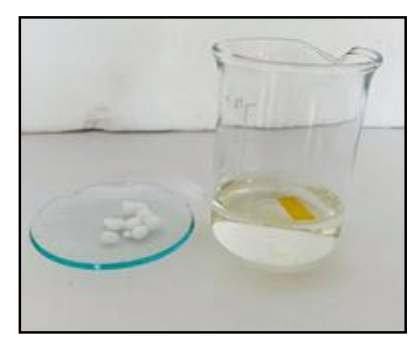

d) Determining the $\mathrm{pH}$ of distilled water

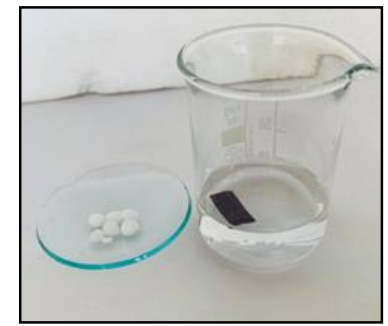

e) Determining the $\mathrm{pH}$ of $\mathrm{NaOH}$ solution

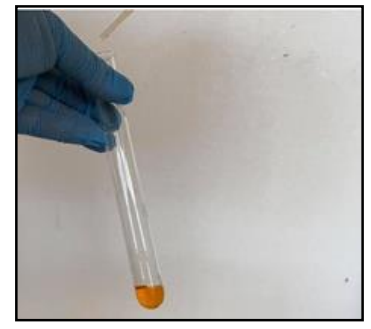

f) Indicator methyl orange in $\mathrm{NaOH}$ solution

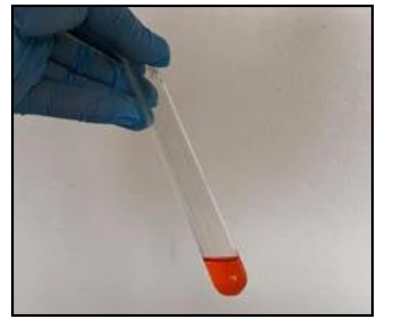

g) Indicator color change by adding the last drop of $\mathrm{HCl}$ solution

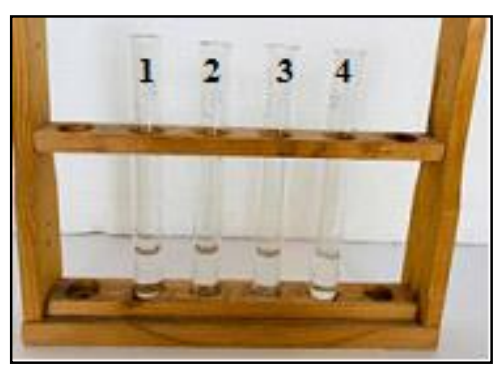

h) 1) $\mathrm{NaCl}$; 2) $\mathrm{NH}_{4} \mathrm{Cl}$; 3) $\mathrm{K}_{2} \mathrm{CO}_{3}$; 4) $\mathrm{NaHCO}_{3}$ aqueous solutions

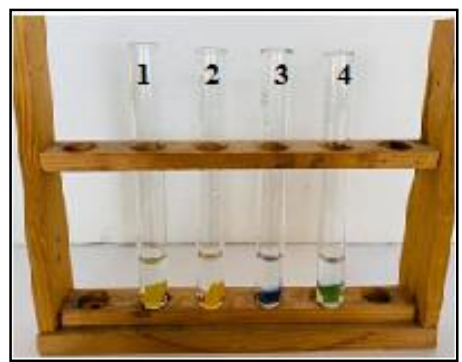

i) determining the $\mathrm{pH}$ of: 1) $\mathrm{NaCl}$;2) $\mathrm{NH}_{4} \mathrm{Cl}$; 3) $\mathrm{K}_{2} \mathrm{CO}_{3}$; 4) $\mathrm{NaHCO}_{3}$ solutions

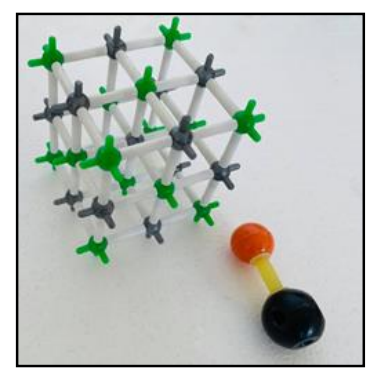

g) $\mathrm{NaCl}$ и $\mathrm{HCl}$ models

Fig. 2. Models and experiments used during the lessons

This research was divided into several phases:

1) distribution of a pre-test,

2) analysis of the pre-test data with the SPSS Statistics 26 software package,

3 ) identifying the misconceptions and the students who have those misconceptions,

4) implementation of the intervention,

5) distribution of a post-test,

6) analysis of the post-test data with the SPSS Statistics 26 software package,

7) conducting individual interviews, and

8) preparing transcripts and analyzing interviews.

The research started with the analysis of the students' grades to gain insight into their achievements in chemistry. Then, in agreement with the subject teacher and according to the previously mentioned phases of research, precisely determined teaching contents were delivered.

\subsubsection{Research sample}

In order to examine the presence and prevalence of misconceptions regarding certain concepts related to acids, bases, and indicators, research was conducted in seven primary schools in the Republic of Macedonia in the period from March to June 2019. The research sample comprised 470 students (13-14 years old), 236 from the $8^{\text {th }}$ and 234 from the $9^{\text {th }}$ grade, which is quite enough for further analysis [41].

Students were divided into two groups: control group (CG), in which the lessons were designed by the subject teacher according to the directions in the curriculum, and experimental group (EG), in which specially designed instructions were applied, including experiments related to the teaching content.

\subsubsection{Research instruments}

The evaluation was done using mixedmethods approach, i.e., a combination of qualitative and quantitative data. The usage of more data 
collection techniques (triangulation) leads to an increase in the validity of the results. Namely, data were collected using two types of instruments: tests and individual interviews with students.

The pre-test-post-test design was used to gain insight into the students' knowledge of the topic and to address the possible misconceptions. The testing was conducted before and after delivering the instructional contents, and the test (Supplementary material) consisted of 11 questions. Ten questions were multiple choice questions, with four options offered, only one of which was correct. Some of the misconceptions known in the literature [1, 42, 43] were inserted as distractors. The eleventh question was a short answer question and the students had to write a chemical equation of a neutralization reaction. The test questions were suitable for both $8^{\text {th }}$ and $9^{\text {th }}$ grade students and were examined by eminent educators in the field of chemistry and chemistry education who ensured the instrument's face and content validity. Namely, as part of the development process, a team of three experts (one university chemistry professor, one primary school chemistry teacher, and one advisor for chemistry teaching, selected according to the criteria of being recognized in the field) were consulted to examine the questions and to give their professional judgements whether the instrument fairly and adequately covered the concepts and objectives being tested.

Hence, when the first version of the questionnaire was sent to them, they were asked for their opinion on the relevance, clarity, accuracy, readability, and wording of the items, as well as on the format of the test. They also had to assess whether the level of test was appropriate (neither too easy nor too difficult, neither too short nor too long). They were instructed to make any modifications and comments in case of ambiguous, vague, or leading questions, and to offer suggestions for more precise wording of the questions. Experts were also asked to check the correctness of attractors and falsity and plausibility of distractors of each multiple-choice question. After the first review, the experts proposed certain changes and after these changes were inserted into the test, it was sent to them for further review until a consensus on the adequacy of test questions was reached.

At the end of this section, we will report the suggestions of the experts. Most of the remarks referred to clarifying the questions and modifying or replacing some of the distractors. For example, the option acids can burn you was considered ambiguous because it does not apply in general, but is true for some acids, while for others it is false, thus it was replaced with acids form a red colour in water. The second statement of the sixth question was reformulated so that the words weakly basic or weakly acidic were replaced with neutral, basic or acidic. Some changes in the terminology (hydrogen chloride instead of hydrochloric acid) and more specific phrasing ( $\mathrm{HCl}$ instead of acids in the second question and $\mathrm{NaOH}$ instead of hydroxides in the third question) were made. Experts thought that some distractors lacked plausibility, so modifications were suggested (blue instead of green in the fifth question and molecular model instead of cation in the second and third questions). Having all this in mind, we can say that the feedback from the experts was of great importance for increasing the overall quality of the test.

\subsubsection{Data analysis}

Each correct answer was scored one point, so that the maximum score was 11 . The data were subjected to descriptive statistical analysis and statistical testing. Special attention was paid to incorrect answers (distractors) that were represented by more than $20 \%$, which is an indicator of the presence of misconception [44]. Furthermore, a criterion for determining the mastery of the tested concept is known in the literature. Namely, according to Gilbert [45] there are four areas of conceptual understanding:

1) satisfactory conceptual understanding (SCU) if the correct answer is given by $75 \%$ of the students or more,

2) roughly adequate performance (RAP) if this percentage is in a range $50-74 \%$,

3 ) inadequate performance (IP) for percentage range $25-49 \%$, and

4) quite inadequate performance (QIP) if obtained frequency is less than $25 \%$

\section{RESULTS AND DISCUSSION}

The initial analysis of the results obtained after the scoring of the tests indicates that, in general, the students from the $9^{\text {th }}$ grade showed better results in the tests compared to the results achieved by the students from the $8^{\text {th }}$ grade. The level of conceptual understanding, according to the percentage of correct answers given by the $8^{\text {th }}$ and $9^{\text {th }}$ grade students from the control and experimental group to the first ten questions of the test, is shown in Figure 3 and Figure 4. The eleventh question, due to its character (open-ended question), was considered separately. 


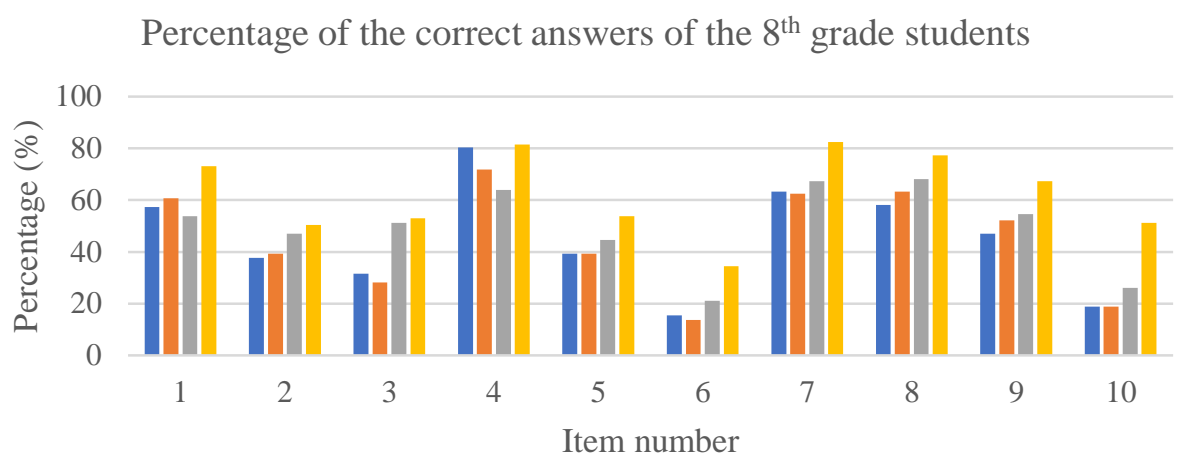

- Percentage of the correct answers of the 8th grade students (\%) CG pre-test
$\square$ Percentage of the correct answers of the 8th grade students (\%) CG post-test
- Percentage of the correct answers of the 8th grade students (\%) EG pre-test
- Percentage of the correct answers of the 8th grade students (\%) EG post-test

Fig. 3. Percentage of the correct answers of the students from the $8^{\text {th }}$ grade from the control and experimental groups of the pre- and post-test

Percentage of the correct answers of the $9^{\text {th }}$ grade students

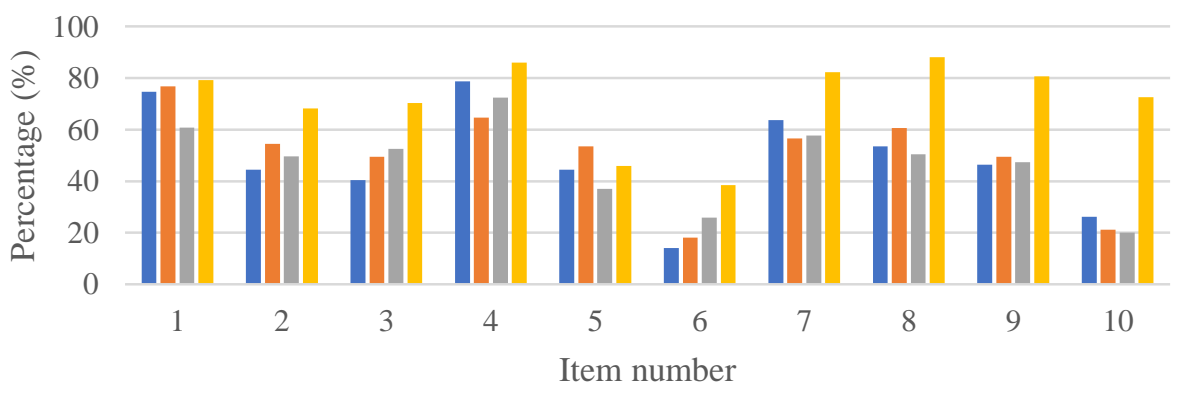

$\square$ Percentage of the correct answers of the 9th grade students (\%) CG pre-test
$\square$ Percentage of the correct answers of the 9th grade students (\%) CG post-test
$\square$ Percentage of the correct answers of the 9th grade students (\%) EG pre-test
$\square$ Percentage of the correct answers of the 9th grade students (\%) EG post-test

Fig. 4. Percentage of the correct answers of the students from the $9^{\text {th }}$ grade from the control and experimental group of the pre- and post-test

The $8^{\text {th }}$ grade students pre-test results in the control group showed SCU of students for only one question, RAP for three questions, and IP for four questions. The area covered by QIP was represented regarding two items. On the post-test, the following results were obtained: for five questions the students showed RAP, for three questions IP, and for two questions QIP. The area covered by SCU was not represented.

SCU was not present in the students from the experimental group on the pre-test. These students indicated RAP for six questions, IP for three questions, and QIP for only one question. On the post- test, these students showed SCU for three questions, RAP for six questions, and IP for one question. The area covered by QIP was not represented.

The results summarized in Figure 4 refer to the achievements of the $9^{\text {th }}$ grade students from the control and experimental group. In the pre-test, the students from the control group showed SCU for one question, RAP for three questions, and IP for five questions. The area covered by QIP was represented for only one item. On the post-test, however, it was noted that students showed SCU for one question, RAP for five questions, IP and QIP for two questions. 
SCU students were not present in the experimental group of the pre-test, for five questions the students showed RAP, and for four questions they showed IP. The area covered by QIP is represented in one item. On the post-test, the students from the experimental group showed the following results: for five questions they showed SCU, RAP for three questions, and IP for two questions. The area covered by QIP was not represented.

Regarding the first research question "Does the implemented intervention contribute to the improvement of students' knowledge and achievements?", it was necessary to compare the achievements of students in CG and EG on the post-test and, based on statistical analysis, to draw a conclusion of the effectiveness of the intervention.
The normality test for samples larger than 50 participants designed by D'Agostino [46] was run as a prerequisite for performing the $t$-test. Results summarized in Table 1 show that $p$-value is higher than 0.05 for all data sets indicating normally distributed data, except for the $9^{\text {th }}$ grade CG students pre-test results and for the $9^{\text {th }}$ grade EG students post-test results. In addition, visual inspection of normal Q-Q plots showed that test scores were approximately normally distributed for both abovementioned groups (data cluster around the trend line). Moreover, when analyzing a series of experiments, it is important to analyze data the same way. Having all this in mind, further analysis involved a $t$-test to compare pre- and post-test results.

Table 1

D'Agostino normality test analysis results

\begin{tabular}{|c|c|c|c|c|c|c|}
\hline & & Skewness & SES* & Kurtosis & "SEK ${ }^{*}$ & $\bar{p} p$-value $\left(\mathrm{K}^{2}\right)$ \\
\hline \multirow{2}{*}{$\begin{array}{c}\text { the } 8^{\text {th }} \text { grade } \\
\text { students' } \\
\text { pre-test }\end{array}$} & CG & .091 & .223 & -.427 & .442 & $\begin{array}{c}0.5190 \\
(1.3117)\end{array}$ \\
\hline & EG & .114 & .223 & -.074 & .442 & $\begin{array}{c}0.8703 \\
(0.2777)\end{array}$ \\
\hline \multirow{2}{*}{$\begin{array}{l}\text { the } 8^{\text {th }} \text { grade } \\
\text { students' } \\
\text { post-test }\end{array}$} & CG & -.141 & .223 & -.645 & .442 & $\begin{array}{c}0.1174 \\
(4.2847) \\
\end{array}$ \\
\hline & EG & -.088 & .223 & -.482 & .442 & $\begin{array}{c}0.4099 \\
(1.7836) \\
\end{array}$ \\
\hline \multirow{2}{*}{$\begin{array}{c}\text { the } 9^{\text {th }} \text { grade } \\
\text { students' } \\
\text { pre-test }\end{array}$} & CG & .094 & .241 & -.967 & .478 & $\begin{array}{c}0.0016 \\
(12.8914)\end{array}$ \\
\hline & EG & .304 & .209 & -.329 & .416 & $\begin{array}{c}0.2499 \\
(2.7738) \\
\end{array}$ \\
\hline \multirow{2}{*}{$\begin{array}{l}\text { the } 9^{\text {th }} \text { grade } \\
\text { students' } \\
\text { post-test }\end{array}$} & CG & .170 & .241 & -.616 & .478 & $\begin{array}{c}0.1947 \\
(3.2722)\end{array}$ \\
\hline & EG & -.161 & .209 & -.966 & .416 & $\begin{array}{c}0.0001 \\
(18.9784)\end{array}$ \\
\hline
\end{tabular}

* Standard error

First, we checked whether there was an improvement in their achievements in general, i.e., we tested the hypothesis (at a significance level of 0.05 ):

$\mathrm{H}_{0}$ : There is no significant difference between the pre-test and the post-test results.

Comparison of the means of the pre- and post-test results indicates progress in the cognitive achievements of students in both $8^{\text {th }}$ and $9^{\text {th }}$ grades. The results of the paired-samples $t$-test are summarized in Table 2, from which it can be concluded that students (from each grade, but also from the whole sample) showed significantly higher results of the post-test compared to those of the pre-test.

Table 2

Paired-samples t-test analysis results when comparing the results of pre-and post-tests

\begin{tabular}{lllllll}
\hline \hline \multirow{2}{*}{ Grade } & \multicolumn{5}{c}{ Pre-test } & \multicolumn{5}{c}{ Post-test } \\
\cline { 2 - 7 } & $\boldsymbol{N}^{*}$ & $\overline{\boldsymbol{x}}^{*}$ & $\boldsymbol{s}^{*}$ & $\overline{\boldsymbol{x}}$ & $\boldsymbol{t}^{* *}$ \\
\hline $8^{\text {th }}$ & 236 & 5.015 & 1.994 & 5.811 & 2.262 & 6.0604 \\
$9^{\text {th }}$ & 234 & 5.128 & 2.355 & 6.754 & 2.412 & 10.7048 \\
\hline Total & 470 & 5.071 & 2.180 & 6.281 & 2.383 & 11.8489 \\
\hline \hline
\end{tabular}

${ }^{*} N, \bar{x}$ and $s$ denote number of students, mean and standard deviation of the sample, respectively *** $p<0.0001$ 
To determine if there is a significant difference in the results between the CG and EG students on the pre- and post-test, respectively, an independent-samples $t$-test was performed. The null hypotheses, for the sample of the $8^{\text {th }}$ grade students, were formulated as:

$\mathrm{H}_{0}$ : There is no significant difference between the results of the $8^{\text {th }}$ grade students from $C G$ and $E G$ on the pre-test.

and

$\mathrm{H}_{0}$ : There is no significant difference between the results of the $8^{\text {th }}$ grade students from $C G$ and $E G$ on the post-test. and the results are summarized in Table 3.

The same was done for the $9^{\text {th }}$ grade students. The results from testing the hypotheses:

$\mathrm{H}_{0}$ : There is no significant difference between the results of the $9^{\text {th }}$ grade students from $C G$ and $E G$ on the pre-test.

and

$\mathrm{H}_{0}$ : There is no significant difference between the results of the $9^{\text {th }}$ grade students from $C G$ and EG on the post-test.

are given in Table 4.

Table 3

Independent-samples t-test analysis results in relation to the achievements of the students from the $8^{\text {th }}$ grade on the pre-and post-test

\begin{tabular}{ccccccc}
\hline \hline & $\mathbf{8}^{\text {th }}$ grade & $\boldsymbol{N}$ & $\overline{\boldsymbol{x}}$ & $\boldsymbol{s}$ & $\boldsymbol{t}$ & $\boldsymbol{p}$ \\
\hline \multirow{2}{*}{ Pre-test } & EG & 118 & 5,246 & 2,063 & \multirow{2}{*}{1,7876} & 0,0751 \\
& CG & 118 & 4,784 & 1,903 & & \multirow{2}{*}{0,0001} \\
\hline \multirow{2}{*}{ Post-test } & EG & 118 & 6,797 & 2,086 & \multirow{2}{*}{7,4208} & \\
& CG & 118 & 4,826 & 1,992 & & \\
\hline \hline
\end{tabular}

Table 4

Independent-samples t-test analysis results in relation to the achievements of the students from the $9^{\text {th }}$ grade on the pre-and post-test

\begin{tabular}{ccccccc}
\hline \hline & $\boldsymbol{9}^{\text {th }}$ grade & $\boldsymbol{N}$ & $\overline{\boldsymbol{x}}$ & $\boldsymbol{s}$ & $\boldsymbol{t}$ & $\boldsymbol{p}$ \\
\hline \multirow{2}{*}{ Pre-test } & EG & 134 & 5,045 & 2,267 & \multirow{2}{*}{0,6265} & 0,5316 \\
& CG & 100 & 5,240 & 2,476 & & \multirow{2}{*}{0,0001} \\
\hline \multirow{2}{*}{ Post-test } & EG & 134 & 7,698 & 2,040 & \multirow{2}{*}{7,7559} & \\
& CG & 100 & 5,490 & 2,298 & & \\
\hline \hline
\end{tabular}

The analysis showed that there are no significant differences between the CG and EG students responses in the pre-test at a significance level of 0.05 (null hypotheses, in relation to the pre-test, are accepted). This was observed in both the $8^{\text {th }}$ grade sample $(p=0.0751)$ and the $9^{\text {th }}$ grade sample $(p=0.5316)$. Hence, it can be concluded that the two groups (CG and EG) in both grades were identical in terms of their achievements at the beginning of the research.

When comparing the CG and EG students' achievements on the post-test, it was noticed that the EG students showed significantly higher results than the CG students. This trend was present in both the $8^{\text {th }}$ and $9^{\text {th }}$ grade $(p<0.0001)$. Based on this, the null hypotheses regarding the post-test are rejected. The significantly better results of the EG students on the post-test indicate the fact that the intervention had a positive effect on the learning process and is more effective than the usual way of teaching. We can say that one of the main reasons for the success of such interventions is the confrontation of students with their previously acquired misconceptions and providing the opportunity to form the right conclusions that are scientifically correct. This finding has been confirmed in several previous studies $[39,47]$

Regarding the second research question: "Is there a trend in the perceptions the of $8^{\text {th }}$ and $9^{\text {th }}$ grade students?", it can be seen that $t$ values increase from the $8^{\text {th }}$ grade sample to the $9^{\text {th }}$ grade one (Table 2).

The third research question was: "Are there (if yes, which) misconceptions about the acids and bases concepts among students?". Students' re- 
sponses to pre-test were used as a basis for assessing the degree of conceptual understanding and the misconceptions present. These responses were compared with post-test results. Eight misconceptions from the first ten questions were observed on the pre-test in CG students and six in EG students. The eleventh question, due to its character (openended question), was considered separately. The number of misconceptions was reduced in the posttest (six in the control and three in the experi- mental group), as well as their percentage. However, there were some deep-rooted misconceptions that remained practically unchanged after delivering the lessons in CG and EG. It can be seen from Table 5 that most of the misconceptions remain on the post-test in the CG students (M1, M2, M3, M4.1, M4.2, and M6.2), while in the EG students there is a more noticeable decrease in the number of misconceptions (only misconceptions M1, M3, M4.1 appeared on the post-test).

Table 5

Located misconceptions after test analysis

\begin{tabular}{|c|c|c|c|c|c|}
\hline \multirow[b]{2}{*}{$\begin{array}{c}\text { Item } \\
\text { number }\end{array}$} & \multirow[b]{2}{*}{ Misconception } & \multicolumn{4}{|c|}{ Percentage of misconceptions (\%) } \\
\hline & & $\begin{array}{c}\text { CG } \\
\text { pre-test }\end{array}$ & $\begin{array}{c}\text { CG } \\
\text { post-test }\end{array}$ & $\begin{array}{c}\text { EG } \\
\text { pre-test }\end{array}$ & $\begin{array}{c}\text { EG } \\
\text { post-test }\end{array}$ \\
\hline 2 & $\begin{array}{l}\text { M1: } \mathrm{HCl} \text { may represent hydrogen chloride } \\
\text { formula unit. }\end{array}$ & $\begin{array}{c}31.48 \\
\left(8^{\text {th }}-30.77\right. \\
\left.9^{\text {th }}-32.32\right)\end{array}$ & $\begin{array}{c}34.72 \\
\left(8^{\text {th }}-39.32\right. \\
\left.9^{\text {th }}-29.29\right)\end{array}$ & $\begin{array}{c}33.46 \\
\left(8^{\text {th }}-33.61\right. \\
\left.9^{\text {th }}-33.33\right)\end{array}$ & $\begin{array}{c}27.17 \\
\left(8^{\text {th }}-31.09\right. \\
\left.9^{\text {th }}-23.70\right)\end{array}$ \\
\hline 3 & $\begin{array}{l}\text { M2: } \mathrm{NaOH} \text { may represent sodium hydroxide } \\
\text { molecule. }\end{array}$ & $\begin{array}{c}33.80 \\
\left(8^{\text {th }}-32.48\right. \\
\left.9^{\text {th }}-35.35\right)\end{array}$ & $\begin{array}{c}42.13 \\
\left(8^{\text {th }}-50.43\right. \\
\left.9^{\text {th }}-32.32\right)\end{array}$ & $\begin{array}{c}24.02 \\
\left(8^{\text {th }}-24.37\right. \\
\left.9^{\text {th }}-23.70\right)\end{array}$ & $\begin{array}{c}/(19.2) \\
\left(8^{\text {th }}-24.37\right. \\
\left.9^{\text {th }}-14.81\right)\end{array}$ \\
\hline 5 & $\begin{array}{l}\text { M3: Acid-base indicator is a substance that is } \\
\text { red in acidic and blue in basic solution. }\end{array}$ & $\begin{array}{c}40.28 \\
\left(8^{\text {th }}-40.17\right. \\
\left.9^{\text {th }}-40.40\right)\end{array}$ & $\begin{array}{c}38.43 \\
\left(8^{\text {th }}-45.30\right. \\
\left.9^{\text {th }}-30.30\right)\end{array}$ & $\begin{array}{c}48.43 \\
\left(8^{\text {th }}-46.22\right. \\
\left.9^{\text {th }}-50.37\right)\end{array}$ & $\begin{array}{c}42.13 \\
\left(8^{\text {th }}-33.61\right. \\
\left.9^{\text {th }}-49.63\right)\end{array}$ \\
\hline \multirow[b]{2}{*}{6} & $\begin{array}{l}\text { M4.1: At complete neutralization of any acid } \\
\text { and any base, the medium is always neutral. } \\
\text { If we mix equal volumes of any acid and any } \\
\text { base, the medium will be neutral. }\end{array}$ & $\begin{array}{c}38.89 \\
\left(8^{\text {th }}-32.48\right. \\
\left.9^{\text {th }}-46.46\right)\end{array}$ & $\begin{array}{c}36.57 \\
\left(8^{\text {th }}-39.32\right. \\
\left.9^{\text {th }}-33.33\right)\end{array}$ & $\begin{array}{c}41.34 \\
\left(8^{\text {th }}-48.74\right. \\
\left.9^{\text {th }}-34.81\right)\end{array}$ & $\begin{array}{c}35.58 \\
\left(8^{\text {th }}-42.02\right. \\
\left.9^{\text {th }}-35.56\right)\end{array}$ \\
\hline & $\begin{array}{l}\text { M4.2: At complete neutralization of any acid } \\
\text { and any base, the medium is always neutral. } \\
\text { If we mix equal volumes of any acid and any } \\
\text { base, the medium will be neutral. } \\
\text { If we dissolve any salt in water, the medium } \\
\text { will be neutral. }\end{array}$ & $\begin{array}{c}31.02 \\
\left(8^{\text {th }}-35.90\right. \\
\left.9^{\text {th }}-25.25\right)\end{array}$ & $\begin{array}{c}31.94 \\
\left(8^{\text {th }}-32.48\right. \\
\left.9^{\text {th }}-31.31\right)\end{array}$ & $\begin{array}{c}/ \\
(12.20) \\
\left(8^{\text {th }}-15.97\right. \\
\left.9^{\text {th }}-8.89\right)\end{array}$ & $\begin{array}{c}/ \\
(7.87) \\
\left(8^{\text {th }}-13.45\right. \\
\left.9^{\text {th }}-2.96\right)\end{array}$ \\
\hline 9 & $\begin{array}{l}\text { M.5: The acid is neutralized with a base using } \\
\text { titration, so that the acid and the corresponding } \\
\text { indicator are put in the Erlenmeyer flask first. } \\
\text { Then, drop by drop, the base is added from the } \\
\text { burette. What happens to the pH after the base } \\
\text { has been added to the Erlenmeyer flask? } \\
\text { Whether the pH will increase or decrease } \\
\text { depends on which acid and which base are } \\
\text { used. }\end{array}$ & $\begin{array}{c}20.37 \\
\left(8^{\text {th }}-15.38\right. \\
\left.9^{\text {th }}-26.26\right)\end{array}$ & $\begin{array}{c}/ \\
(19.44) \\
\left(8^{\text {th }}-18.80\right. \\
\left.9^{\text {th }}-20.20\right)\end{array}$ & $\begin{array}{c}/ \\
(17.72) \\
\left(8^{\text {th }}-16.81\right. \\
\left.9^{\text {th }}-18.52\right)\end{array}$ & $\begin{array}{c}/ \\
(10.24) \\
\left(8^{\text {th }}-13.45\right. \\
\left.9^{\text {th }}-7.41\right)\end{array}$ \\
\hline \multirow{2}{*}{10} & $\begin{array}{l}\text { The medium of aqueous solutions prepared } \\
\text { from the following salts: } \mathrm{NaCl}, \mathrm{NH}_{4} \mathrm{Cl} \text {, } \\
\mathrm{K}_{2} \mathrm{CO}_{3} \text { and } \mathrm{NaHCO}_{3} \text { will be: } \\
\text { M.6.1: weakly acidic }\end{array}$ & $\begin{array}{c}24.07 \\
\left(8^{\text {th }}-23.93\right. \\
\left.9^{\text {th }}-24.24\right)\end{array}$ & $\begin{array}{c}/ \\
(17.59) \\
\left(8^{\text {th }}-17.95\right. \\
\left.9^{\text {th }}-17.17\right)\end{array}$ & $\begin{array}{c}22.05 \\
\left(8^{\text {th }}-29.41\right. \\
\left.9^{\text {th }}-15.56\right)\end{array}$ & $\begin{array}{c}/ \\
(11.02) \\
\left(8^{\text {th }}-17.65,\right. \\
\left.9^{\text {th }}-5.19\right)\end{array}$ \\
\hline & M6.2: neutral & $\begin{array}{c}29.36 \\
\left(8^{\text {th }}-33.33\right. \\
\left.9^{\text {th }}-25.25\right)\end{array}$ & $\begin{array}{c}39.35 \\
\left(8^{\text {th }}-41.88\right. \\
\left.9^{\text {th }}-36.36\right)\end{array}$ & $\begin{array}{c}41.73 \\
\left(8^{\text {th }}-25.21\right. \\
\left.9^{\text {th }}-56.30\right)\end{array}$ & $\begin{array}{c}/ \\
(14.17) \\
\left(8^{\text {th }}-15.13,\right. \\
\left.9^{\text {th }}-13.33\right)\end{array}$ \\
\hline
\end{tabular}


Some of the misconceptions found in our study have also been documented in previous studies. The first two misconceptions (Table 5) indicate students' misinterpretations with three levels of thinking i.e., the misconceptions due to the connection of these levels. In previous studies [48] misconceptions concerning the building particles in ionic substances were investigated and during the interviews, the students' belief that entities in ionic substances resemble covalent ones was revealed (e.g., "When it is not dissolved, molecules are present. In an aqueous solution ions are formed"). According to Kelly et al. [30] students tend to fit their submicroscopic-level ideas to the equations, and when introduced to molecular equations, oftentimes they conclude that the formulae represent molecules. Their study shows that students do not realize that some compounds are initially composed of ions.

Experimental activities, such as color change of an indicator in acidic or basic solution are useful and fun for students, but they only cover the macroscopic level of thinking. Unless accompanied by further explanations involving the microscopic and symbolic levels, they can lead to poor understanding of the concepts. An interesting activity was designed by Putti [49] to study the difference between strong and weak acids on a particulate level.

Furthermore, misconceptions about neutralization and neutral solutions, addressed in several questions in our instrument, are confirmed by many authors as well $[3,14,15,39,50]$. Thus, Demircioğlu [39] found that the opinion that neutralization always results in a neutral solution is quite common among students, probably due to the fact that the term neutral has different meanings in the scientific literature and in everyday application [50, 51]. Drechsler and Schmidt [52] offered an explanation of the statement that the reaction between equivalent amounts of an acid and a base should always result in a neutral solution, claiming that it is not always true and giving the reaction between acetic acid and sodium hydroxide as an example, in which a basic (not neutral) solution is obtained. They derive this reasoning (specified in the statement above) from the analysis of textbooks in which through equations it is suggested that acids and bases consume each other. Other studies [14, 15] have shown students' views that mixing any kind of acids and bases (irrespective of their nature and quantities) would give a neutral solution. Such views were observed among adults as well [53]. Cokelez [15] even suggests that the term neutralization should be avoided in the teaching process.

\section{CONCLUSION}

The purpose of the research was to gain insight into the students' knowledge and address any possible misconceptions that they might have about the acids and bases concepts, but also about other concepts that are closely related to them (particle theory of matter, solubility, neutralization). In the experimental group, in contrast to the control group, a different approach to teaching was applied. Moreover, the intervention in EG involved both experimental work and a discussion section, which enabled the activation of a higher order thinking skills. The intervention was in correlation to the current curricula, in order to improve students' understanding of the acids and bases concepts and to eliminate (or reduce) misconceptions.

Based on the achievements of the students from CG and EG on the post-test, it can be noticed that the EG students showed significantly higher results than the CG students. This applies to both $8^{\text {th }}$ and $9^{\text {th }}$ grade students $(p<0.0001)$. The significantly better results of the EG students on the posttest indicate that the intervention had a positive effect on the learning process and is more effective than the usual way of teaching.

The results obtained from the tests indicate that certain concepts were not completely clear. Several misconceptions about this topic were identified among students. Some misconceptions were less prevalent in the post-test, but there were also entrenched misconceptions that remained after the intervention. Such findings are in agreement with the previous research in this field [11, 20, 26, 54] which states that some misconceptions are resistant to change although the intervention was applied. Of course, one cannot expect the misconceptions to disappear completely after one intervention. Therefore, it is important to consider the knowledge gained from such studies as good teaching practices that will be widespread and applied by inservice teachers, but it is recommended that they have a place in the teacher education programs [55, 56] as it is likely that pre-service teachers also hold some misconceptions [57-59] which can be transmitted to their students [54]. Due to the fact that some misconceptions stem from pedagogical practices, awareness and carefully constructed instruction are needed to prevent such misconceptions, so teachers will be better equipped to recognize them [60]. They should be able to diagnose errors in stu- 
dent thinking, address misconceptions and apply suitable strategies and teaching methods to correct them.

As mentioned, it is not excluded that such misconceptions are present not only among students, but also among teachers and researchers themselves, in textbooks or curricula. It is very important to carefully write the curricula and textbooks, but teachers must also be careful when implementing the curriculum. Of course, the age of the students plays a big role in deciding what and at what level to study, but generating misconceptions in the initial period of studying chemistry must not be allowed because what will be learned first is forgotten last. Therefore, it is necessary to pay great attention when defining key terms and concepts in chemistry. On the other hand, persuasive experiments can greatly contribute to a correct understanding of concepts.

\section{REFERENCES}

[1] C. Horton, Student alternative conceptions in chemistry, California Journal of Science Education, 7, 1-78 (2007).

[2] Cambridge Dictionaries Online, http://dictionary. cambridge.org/dictionary/british/misconception, assessed $\mathrm{Au}$ gust 2021.

[3] B. K. Bayrak, H. Bayram, Effects of problem-based learning in a web environment on conceptual understanding: The subject of acids and bases, Int. Online J. Educ. Sci., 3, 831-848 (2011).

[4] P. G. Nelson, Basic chemical concepts, Chem. Educ. Res. Pract., 4, 19-24 (2003).

DOI: https://doi.org/10.1039/B2RP90033E

[5] H. D. Barke, A. Hazari, S. Yitbarek, students' misconceptions and how to overcome them in: Misconceptions in Chemistry. Addressing Perceptions in Chemical Education, Springer-Verlag, Berlin, 2009, pp. 21-36.

[6] G. Papageorgiou, D. Sakka, Primary school teachers' views of fundamental chemical concepts, Chem. Educ. Res. Pract., 1, 237-247 (2000).

DOI: https://doi.org/10.1039/A9RP90025J

[7] K. S. Taber, M. Watts, Learners' explanations for chemical phenomena, Chem. Educ. Res. Pract., 1, 329353 (2000). DOI: https://doi.org/10.1039/B0RP90015J

[8] R. Artdej, T. Ratanaroutai, R. K. Coll, T. Thongpanchang, Thai Grade 11 students' alternative conceptions for acid-base chemistry, Res. Sci. Technol. Educ., 28 , 167-183 (2010).

DOI: https://doi.org/10.1080/02635141003748382

[9] S. Sadhu, M. T. Tima, V. P. Cahyani, A. F. Laka, D. Annisa, A. R. Fahriyah, Analysis of acid-base misconceptions using modified certainty of response index (CRI) and diagnostic interview for different student levels cognitive, Int. J. Sci. Appl. Sci.: Conf. Ser., 1, 91-100 (2016). DOI: https://doi.org/10.20961/ijsascs.v1i2.5126
[10] U. Lathifa, Correcting students' misconception in acid and base concept using PDEODE instruction strategy, Unnes Sci. Edu. J., 7, 170-177 (2018). DOI: 10.15294/USEJ.V7I2.23202

[11] F. D. Mubarokah, S. Mulyani, N. Y. Indriyanti, Identifying students' misconceptions of acid-base concepts using a three-tier diagnostic test: A case of indonesia and thailand, J. Turk. Sci. Educ., 15 (Special Issue), 51-58 (2018). DOI: 10.12973/tused.10256a

[12] A. Lembens, S. Hammerschmid, S. Jaklin-Farcher, C. Nosko, K. Reiter. Textbooks as source for conceptional confusion in teaching and learning 'acids and bases' in lower secondary school, Chemistry Teacher International, 1, 20180029 (2019). DOI: https://doi.org/10.1515/cti-2018-0029

[13] K. Shepard, High school students' understanding of titrations and related acid base phenomena, Chem. Educ. Res. Pract., 7, 32-45 (2006). DOI: https://doi.org/10.1039/B5RP90014J

[14] J. Lin, Jing-Wen and M. Chiu, Mei-Hung, Exploring the characteristics and diverse sources of students' mental models of acids and bases, Int. J. Sci. Educ., 29, 771803 (2007). DOI: http://dx.doi.org/10.1080/09500690600855559

[15] A. Cokelez, A Comparative study of French and Turkish students' ideas on acid-base reactions, J. Chem. Educ., 87, 102-106 (2010). DOI: https://doi.org/10.1021/ed800017b

[16] M. I. M. Damanhuri, D. F. Treagust, M. Won, A. L. Chandrasegaran, High school students' understanding of acid-base concepts: An ongoing challenge for teachers, Int. J. Environ. Sci. Educ., 11, 9-27 (2016). DOI: $10.12973 /$ ijese.2015.284a

[17] M. M. Cooper, H. Kouyoumdjian, S. M. Underwood, Investigating students' reasoning about acid-base reactions, J. Chem. Educ., 93, 1703-1712 (2016). DOI: https://doi.org/10.1021/acs.jchemed.6b00417

[18] R. Duit, D. F. Treagust, A. Widodo, Teaching science for conceptual change: theory and practice. In: International Handbook of Research on Conceptual Change, S. Vosniadou (Ed.), New York: Routledge, 2008, pp. 629 646.

[19] İ. Bilgin, Ö. Geban, The effect of cooperative learning approach based on conceptual change condition on students' understanding of chemical equilibrium concepts, J. Sci. Educ. Technol., 15, 31-46 (2006). DOI: https://doi.org/10.1007/s10956-006-0354-z

[20] G. Demircioglu, A. Ayasa, H. Demircioglu, Conceptual change achieved through a new teaching program on acids and bases, Chem. Educ. Res. Pract., 6, 36-51 (2005). DOI: https://doi.org/10.1039/B4RP90003K

[21] R. Duit, D. F. Treagust, Conceptual change: A powerful framework for improving science teaching and learning, Int. J. Sci. Educ., 25, 671-688 (2003). DOI: http://dx.doi.org/10.1080/09500690305016

[22] M. Stojanovska, Conceptual understanding of solubility concepts among first-grade high-school students, The Contributions, Sec. Nat. Math. Biotech. Sci., 38, 109-115 (2017).

DOI: http://dx.doi.org/10.20903/csnmbs.masa.2017.38.1.107 
[23] R. S. Rohmah, I. A. Virtayanti, Effect of conceptual change text on basic chemistry students' understanding of acid and base in online learning, The 4th International Conference on Mathematics and Science Education (ICoMSE), AIP Conference Proceedings 2330, 020002 (2021). DOI: https://doi.org/10.1063/5.0043141

[24] M. Hugerat, N. Najami, R. Abu-Much, W. Khatib, A. hofstein, making the learning of acid-base concepts more relevant - A research study, J. Lab. Chem. Educ., 6, 36-45 (2018).

DOI: $10.5923 /$ j.jlce.20180602.04

[25] G. J. Posner, K. A. Strike, P. W. Hewson, W. A. Gertzog, Accommodation of a scientific conception: toward a theory of conceptual change, Sci. Educ., 66, 211-227 (1982).

DOI: https://doi.org/10.1002/sce.3730660207

[26] S. Vosniadou, C. Ioannides, A. Dimitrakopoulou, E. Papademetriou, Designing learning environments to promote conceptual change in science, Learn. Instr., 11, 381-419 (2001).

DOI: https://doi.org/10.1016/S0959-4752(00)00038-4

[27] R. H. Duit, D. F. Treagust, Conceptual change: Still a powerful framework for improving the practice of science instruction. In: Issues and Challenges in Science Education Research, K. Tan, M. Kim (Eds.), Springer, 2012, pp. 43-54. DOI: 10.1007/978-94-007-3980-2_4

[28] P. R. Pintrich, R. W. Marx, R. A. Boyle, Beyond cold conceptual change: The role of motivational beliefs and classroom contextual factors in the process of conceptual change, Rev. Educ. Res., 63, 167-199 (1993). DOI: https://doi.org/10.3102/00346543063002167

[29] K. S. Taber, Challenging misconceptions in the chemistry classroom: resources to support teachers, Educ. Quim., 4, 13-20 (2009). DOI: 10.2436/20.2003.02.27

[30] R. M. Kelly, J. H. Barrera, S. C. Mohamed, An analysis of undergraduate general chemistry students' misconceptions of the submicroscopic level of precipitation reactions, J. Chem. Educ., 87, 113-118 (2010). DOI: https://doi.org/10.1021/ed800011a

[31] D. D. Milenković, M. D. Segedinac, T. N. Hrin, S. Horvat, The impact of instructional strategy based on the triplet model of content representation on elimination of students' misconceptions regarding inorganic reactions, J. Serb. Chem. Soc., 81, 717-728 (2016). DOI: https://doi.org/10.2298/JSC150812021M

[32] H. Ö. Kapici, H. Akcay, Particulate nature of matter misconceptions held by middle and high school students in Turkey, Eur. J. Educ. Stud., 2, 43-58 (2016). DOI: https://doi.org/10.5281/zenodo.163547

[33] V. Ferk Savec, B. Urankar, M. K. Aksela, I. Devetak, Prospective chemistry teachers' perceptions of their profession: the state of the art in Slovenia and Finland, $J$. Serb. Chem. Soc., 82, 1193-1210 (2017). DOI: https://doi.org/10.2298/JSC161221083S

[34] H. Johnstone, Why is science difficult to learn? Things are seldom what they seem, J. Comput. Assist. Learn, 7, 75-83 (1991). DOI: https://doi.org/10.1111/j.1365-2729.1991.tb00230.x

[35] D. Forbes, R. Fosbery, A. Fullick, V. Newman, R. Norris, L. Ryan, Essential Science for Cambridge Secondary 1 Stage 8 Pupils Book (Chemistry), Ars Lamina, Skopje, 2016, p. 62 (in Macedonian).
[36] T. L. Brown, H. E. LeMay, B. E. Bursten, C. J. Murohy, P. M. Woodward, Chemistry. The Central Science $\left(12^{\text {th }}\right.$ ed.), MA: Prentice Hall, Boston, 2012.

[37] J. Pelech, G. Pieper, The Comprehensive Handbook of Constructivist Teaching, Charlotte, NC: Information age publishing, 2010.

[38] Bureau of the Development of Education, www.bro.gov.mk, assessed August 2021.

[39] G. Demđrcđoğlu, Comparison of the effects of conceptual change texts implemented after and before instruction on secondary school students' understanding of acid-base concepts, Asia-Pac. Forum Sci. Learn. Teach., 10, Article 5 (2009).

[40] E. Ural, D. M. Gençoğlan, The Effect of argumentationbased science teaching approach on $8^{\text {th }}$ graders' learning in the subject of acids-bases, their attitudes towards science class and scientific process skills, Interdiscip. J. Environ. Sci. Educ., 16, e02207 (2020). DOI: https://doi.org/10.29333/ijese/6369

[41] K. E. Hoque, G. M. Alam, M. R. B. M. Ariff, P. K. Mishra, T. G. Rabby, Site-based management: Impact of leader's roles on institutional improvement, Afr. J. Bus. Manage., 5, 3623-3629 (2011).

[42] V. Kind, Beyond Appearances: Students' Misconceptions about Basic Chemical Ideas ( $2^{\text {nd }}$ ed.), Durham University, Durham, 2004.

[43] E. J. Yezierski, J. P. Birk, Misconceptions about the particulate nature of matter. Using animations to close the gender gap, Chem. Educ., 83, 954-960 (2006). DOI: $10.1021 /$ ed083p954

[44] H. S. Dhindsa, D. F. Treagust, Conceptual understanding of Bruneian tertiary students: Chemical bonding and structure, Brunei Int. J. of Sci. \& Math. Edu., 1, 33-51 (2009).

[45] J. K. Gilbert, The study of student misunderstandings in the physical sciences, Res. Sci. Educ., 7, 165-171 (1977).

[46] R. B. D'Agostino, An Omnibus Test of normality for moderate and large size samples, Biometrika, 58, 341348 (1971). DOI:10.2307/2334522

[47] F. Yaman, A. Ayas, M. Çalık, Facilitating grade 11 students' conceptual understanding of fundamental acidbase models, Turk. J. Educ., 8, 16-32 (2019). DOI: https://doi.org/10.19128/turje.449100

[48] M. Stojanovska, V. M. Petruševski, B. Šoptrajanov, Study of the use of the three levels of thinking and representation, The Contributions, Sec. Nat. Math. Biotech. Sci., 35, 37-46 (2014).

DOI: http://dx.doi.org/10.20903/csnmbs.masa.2014.35.1.52

[49] A. Putti, JCE classroom activity \#109: My acid can beat up your acid!, J. Chem. Educ., 88, 1278-1280 (2011). DOI: https://doi.org/10.1021/ed100849b

[50] H. J. Schmidt, A label as a hidden persuader: chemists. Neutralization concept, Int. J. Sci. Educ., 13, 459-471 (1991). DOI: https://doi.org/10.1080/0950069910130409

[51] M. B. Nakhleh, Why some students don't learn chemistry, J. Chem. Educ., 69, 191-196 (1992). DOI: https://doi.org/10.1021/ed069p191

[52] M. Drechsler, H. J. Schmidt, Textbooks' and teachers' understanding of acid-base models used in chemistry teaching, Chem. Educ. Res. Pract., 6, 19-35 (2005). DOI: https://doi.org/10.1039/B4RP90002B 
[53] A. Bučková, M. Prokša, The persistence of primary school students' initial ideas about acids and bases in the mental models of adults, Chem. Educ. Res. Pract., 22, 164-174 (2021).

DOI: https://doi.org/10.1039/D0RP00156B

[54] N. Ültay, M. Calik M., A comparison of different teaching designs of 'acids and bases' subject, EURASIA $J$. Math. Sci. Tech. Ed., 12, 57-86 (2016).

DOI: https://doi.org/10.12973/eurasia.2016.1422a

[55] M. Stojanovska, V. Petruševski, H. G. Köller, S. Karlsen, Students' alternative conceptions and ways to overcome them. In: A Guidebook of Good Practice for the Pre-Service Training of Chemistry Teachers, I. Maciejowska, B. Byers (Eds.), Faculty of Chemistry, Jagiellonian University, 2015, pp. 175-203.

[56] V. Mellado, The classroom practice of preservice teachers and their conceptions of teaching and learning science, Sci. Educ., 82, 197-214 (1998).

DOI:.https://doi.org/10.1002/(SICI)1098-237X(199804)82: 2<197::AID-SCE5>3.0.CO;2-9
[57] J. W. Lin, A comparison of experienced and preservice elementary school teachers' content knowledge and pedagogical content knowledge about electric circuits, EURASIA J. Math. Sci. Tech. Ed., 13, 835-856 (2017). DOI: https://doi.org/10.12973/eurasia.2017.00646a

[58] M. D. Bradley, J. D. Mosimege, Misconceptions in acids and bases. A comparative study of student teachers with different chemistry backgrounds, S. Afr. J. Chem., 51, 137-145 (1998). DOI: https://hdl.handle.net/10520/AJA03794350_1436

[59] V. Mellado, Preservice teachers' classroom practice and their conceptions of the nature of science. In: International Handbook of Science Education, B. J. Fraser, K. Tobin (Eds.), Dordrecht: Kluwer A. P., 1998, pp. 10931110 .

[60] B. Yakmaci-Guzel, Preservice chemistry teachers in action: an evaluation of attempts for changing high school students' chemistry misconceptions into more scientific conceptions, Chem. Educ. Res. Pract., 14, 95104 (2013). DOI: https://doi.org/10.1039/C2RP20109G 